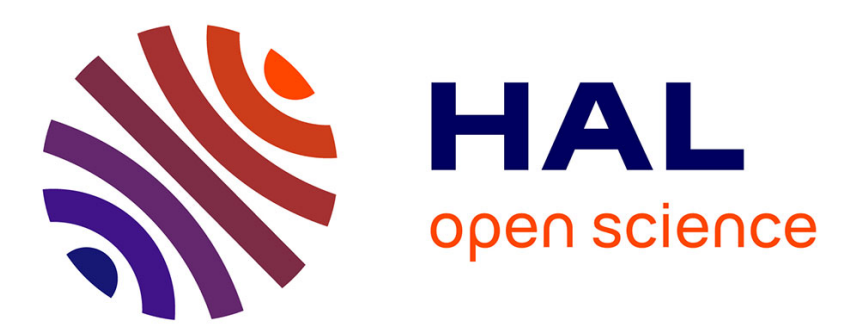

\title{
Scaffold stabilization of a G-triplex and study of its interactions with G-quadruplex targeting ligands
}

\author{
Laureen Bonnat, Maelle Dautriche, Taous Saidi, Johana Revol-Cavalier, \\ Jérôme Dejeu, Eric Defrancq, Thomas Lavergne
}

\section{To cite this version:}

Laureen Bonnat, Maelle Dautriche, Taous Saidi, Johana Revol-Cavalier, Jérôme Dejeu, et al.. Scaffold stabilization of a G-triplex and study of its interactions with G-quadruplex targeting ligands. Organic \& Biomolecular Chemistry, 2019, 17 (38), pp.8726-8736. 10.1039/c9ob01537j . hal-02481507

\section{HAL Id: hal-02481507 https://hal.univ-grenoble-alpes.fr/hal-02481507}

Submitted on 19 Feb 2020

HAL is a multi-disciplinary open access archive for the deposit and dissemination of scientific research documents, whether they are published or not. The documents may come from teaching and research institutions in France or abroad, or from public or private research centers.
L'archive ouverte pluridisciplinaire HAL, est destinée au dépôt et à la diffusion de documents scientifiques de niveau recherche, publiés ou non, émanant des établissements d'enseignement et de recherche français ou étrangers, des laboratoires publics ou privés. 


\title{
Scaffold stabilization of a G-triplex and study of its interactions with G- quadruplex targeting ligands
}

Laureen Bonnat, Maelle Dautriche, Taous Saidi, Johana Revol-Cavalier, Jérôme Dejeu, Eric Defrancq and Thomas Lavergne*

Univ. Grenoble Alpes, Département de Chimie Moléculaire, CNRS, 570 rue de la chimie, CS 40700, Grenoble 38000, France. *e-mail: Thomas.lavergne@univ-grenoble-alpes.fr

\begin{abstract}
G-triplex nucleic acid structures (G3) have been conjectured to form in vivo but little is known about their physiological functions. The identification of ligands capable of specific binding to G3 structures is therefore highly appealing but remains elusive. Here we report on the assembly of a DNA conjugate which fold into a stable G3 structure. The structural mimic was used to probe the interactions between a G3 and first-in-class G4 ligands, revealing signification binding promiscuity.
\end{abstract}

Keywords: G-triplex; G-quadruplex; peptide-oligonucleotide conjugates; G-quadruplex ligands; Click Chemistry; Bio-layer interferometry 


\section{Introduction}

DNA and RNA G-rich sequences have been shown to form G-quadruplex (G4) structures within human cells. ${ }^{1}$ The cellular folding and unfolding of those peculiar nucleic acid structures are now believed to be at the core of a myriad of biological processes. ${ }^{2}$ To unveil the regulatory roles of G4 in biology, significant efforts have been made to identify antibodies and small molecule ligands capable of specifically interacting with G4 structures. ${ }^{3}$ A large number of diseases have also been associated with the improper regulation of those structures and the development of molecules able of either downregulating or upregulating G4 related pathways, by stabilizing or destabilizing those structures, is now considered a worthy approach to treat human pathologies. ${ }^{4}$ While G4 structures were rightly the focus of significant attention, other secondary structures susceptible to emerge from G-rich sequences, such as G-triplex (G3) and G-hairpin structures, have received much less consideration.

Three guanine repeats may lead to the formation of G3 through the stacking of G-G-G triad planes stabilized by Hoogsteen hydrogen bonds (as in Fig. 1a) whereas G-hairpin duplex may form through the formation of G-G base pairs via Hoogsteen or reverse Watson-Crick hydrogen bonds. While initially thought to be short lived intermediates in the folding pathway of G4, the formation of stable G3 and G-hairpin structures has recently been demonstrated. A now significant body of in silico and in vitro experiments have concurred toward the lasting existence of both structures under physiological conditions as exemplified by thermodynamics and spectroscopic studies, ${ }^{5}$ molecular dynamics, ${ }^{6}$ real-time NMR, ${ }^{7}$ single-molecule FRET, ${ }^{8}$ single-

molecule visualization ${ }^{9}$ and structural studies. ${ }^{10}$ Remarkably, while studying the repetitive unfolding of G4 by Pif1 helicase, Hou et al revealed that G3 plays an essential role as the 
structure was found to be a stable intermediate whose binding affinity to Pif1 was superior to that of the parental G4 structure. The strong unfolding activity of Pif1 toward G3 along with the reported ability of G3 to stall a polymerase further support the idea that G3 structures could have important physiological functions. ${ }^{11}$

In this context, the identification of molecules capable of interacting and stabilizing G3 structures is highly appealing to clarify their biological functions and to gage their therapeutic importance. So far, only two studies report on the interaction of small molecule ligand with G3 structures. In 2015, the group of H. Sugiyama reported the solution state-structures of complexes between a small molecule ligand and both a G-hairpin and a G3 structure. ${ }^{12}$ The small molecule was a bisquinolinium derivative (PDC) known to bind G4 structures with high affinity. Therefore, this study suggests that G4 binding ligand may not merely be quadruplex binders but could also bind to alternative intermediate structures. More recently, Randazzo and Coll. have developed novel ligands capable of specifically interacting with a G3 structure and identified promising hits for preferential binding to G3. ${ }^{13}$ Yet the best ligands were also shown to stabilize parallel-stranded G4 structures thereby acting as dual G3/G4 stabilizers.

Those studies suggest that G4 binding ligands of therapeutic significance might not be as specific as initially thought and their interactions with G3 structures should stimulate further investigations. Those studies also emphasize that the identification of structure-specific G3 binding agents remains elusive. The lesser stability of G3 structures, whose stacking surfaces are smaller to those of the G4 structure, makes it difficult to isolate the folded structures and contributes to hamper the development of dedicated targeting ligands.

In the past, our group have dedicated efforts to study the interactions between small-molecule ligands and various G4 structures stabilized into controlled topologies using the TASQ (Template-Assembled Synthetic G-quadruplex) concept. ${ }^{14}$ To do so, we have assembled DNA 
and RNA conjugates capable of mimic naturally occurring G4 structures from the telomeric region of the human genome ${ }^{15}$ and from the HIV genome. ${ }^{16}$ Those conjugates are formed by the covalent association of G4 forming DNA or RNA strands with a rigid and addressable cyclopeptide platform.

In the current study we have assembled two novel DNA-peptide conjugates meant to fold into a stable G3 structure (1) and a parental G4 structure (2) both derived from the human telomeric sequence (Fig. 1). Spectroscopic analyses suggest that both conjugates do fold into their expected conformation and bio-layer interferometry (BLI) was used to investigate the interactions between four prominent G4 binding ligands and both the G4 and G3 mimic structures.

\section{Results and discussion}

\section{Synthesis of conjugates}

To assemble conjugates $\mathbf{1}$ and $\mathbf{2}$, oligonucleotides $4 \mathrm{~d}\left({ }^{5}{ }^{\prime} X\right.$-AGGGTTAGGGT- $\left.Y^{3^{\prime}}\right), \mathbf{5}$ $\mathrm{d}\left({ }^{5}\right.$ 'TAGGGT- $\left.Z^{3}\right)$ or $6 \mathrm{~d}\left({ }^{5}\right.$ 'AGGGTTAGGGT- $Z^{3}$ '), in which $X$ represents a 5'-alkynyl linker, $Y$ a 3'-aldehyde linker and $Z$ a 3'-thiol linker, were attached through stepwise oxime ligation, CuAAC and thiol-SN2 coupling onto cyclopeptide 3 (Scheme 1). Cyclopeptide scaffold 3 was assembled using standard Fmoc/tBu solid phase peptide synthesis (SPPS) on a 2-chlorotrityl resin and cyclized in solution according to reported procedures as described in Scheme S1. ${ }^{16}$ Briefly, a biotin was anchored onto the lower domain of the peptide using a biotin-functionalized lysine building block during SPPS. The azido and aminooxy moieties were introduced during SPPS using a L-azidonorleucine building block and a previously reported lysine building block modified with a protected aminooxyacetic acid (Scheme S1). ${ }^{17}$ The chloroacetamide function was anchored on a lysine side chain after DDE protecting group removal using chloroacetic 
anhydride. To synthesize oligonucleotides $\mathbf{4 , 5}$ and $\mathbf{6}$, solid phase oligonucleotide synthesis (SPOS), using phosphoramidite chemistry, were performed on commercially available glyceryl solid support and disulfide solid support, respectively (Scheme S2 and S3). The alkynyl functional group was introduced at the 5'-terminus of oligonucleotide 4 using commercially available hexynyl phosphoramidite. Following cleavage from the solid support and deprotection steps, oligonucleotide 4 was obtained after oxidative cleavage of the 3'-diol group.

Toward $\mathbf{1}$ and 2, oligonucleotide $\mathbf{4}$ and cyclopeptide $\mathbf{3}$ were first coupled through an oxime bond formation (Scheme 1 and Scheme S4). The synthesis was carried out in ammonium acetate buffer $(\mathrm{pH} 4.5)$ at $55^{\circ} \mathrm{C}$ using a slight excess of aminooxy-containing peptide 3 . The reaction proceeded to completion with $45 \mathrm{~min}$, as evidenced by RP-HPLC, and the crude mixture was purified using RP-HPLC to provide the synthetic intermediate with an isolated yield of $60 \%$. From this intermediate, conjugate 7 was obtained using CuAAC conditions. The intramolecular cyclisation was performed in HEPES buffer, in presence of copper sulfate $\left(\mathrm{CuSO}_{4}\right)$, tris(benzyltriazolylmethyl)amine (THPTA) ligand and sodium ascorbate. The reaction proceeded to completion in $2 \mathrm{~h}$ at room temperature as evidenced by RP-HPLC monitoring. Conjugate 7 was purified using RP-HPLC and the identity and purity of the product were confirmed by RP-HPLC and ESI MS analyses. Toward 1, conjugate 7 bearing a chloroacetamide was reacted with two equivalent of thiol-functionalized oligonucleotide 5 for $5 \mathrm{~h}$ at $\mathrm{pH} 8.5$ in presence of TCEP, to prevent the formation of disulfide species, potassium iodide (KI), N,N-diisopropylethylamine (DIEA) and $500 \mathrm{mM}$ of $\mathrm{KCl}$ as neutralizing cations to minimize repulsions between the negatively charged oligonucleotides. After RP-HPLC purification, conjugate $\mathbf{1}$ was characterized by RP-HPLC and ESI MS analysis, which showed high purity and excellent agreement between the experimentally determined molecular weight and the calculated value. Toward $\mathbf{2}$, conjugate 7 was reacted with two equivalent of thiol-functionalized oligonucleotide 6 under identical 
conditions as for the synthesis of $\mathbf{1}$. Purification using RP-HPLC followed by desalting using SEC afforded pure conjugate 2, with an isolated yield of $60 \%$, according to RP-HPLC and ESI MS analysis (Supporting Information).

\section{Characterization of folded topologies}

Circular dichroism analyses were performed to confirm the formation of a G-triplex structure within conjugate $\mathbf{1}$ and to assess the formation of a G-quadruplex from conjugate $\mathbf{2}$. CD analyses were performed in the presence of monovalent or divalent cations reported to stabilized G-triplex structures, ${ }^{8,} 18$ either $100 \mathrm{mM} \mathrm{KCl}, 100 \mathrm{mM} \mathrm{NaCl}, 100 \mathrm{mM} \mathrm{CaCl}{ }_{2}$ or $100 \mathrm{mM} \mathrm{MgCl}_{2}$ and in the absence of added cations. The $\mathrm{CD}$ spectrum of $\mathbf{1}$ recorded in presence of $\mathrm{K}^{+}$is characterized by two positive peaks at $260 \mathrm{~nm}$ and $290 \mathrm{~nm}$ and one negative peak at $235 \mathrm{~nm}$ (Fig. 2A, purple line). Those values are consistent with previously reported CD spectra of G-triplex DNA stabilized by potassium cations. ${ }^{8,18-19}$

CD spectrum of 1 in presence of $\mathrm{Na}^{+}$show two weak positive peaks at $255 \mathrm{~nm}$ and $290 \mathrm{~nm}$, and two valley at $235 \mathrm{~nm}$ and $275 \mathrm{~nm}$ (Fig. 2A, green line), again consistent with previous reports showing the weak stabilization of G-triplex by Na cations. ${ }^{8,11}$

The $\mathrm{CD}$ spectra of $\mathbf{1}$ in $\mathrm{Ca}^{2+}$ and $\mathrm{Mg}^{2+}$ show a strong positive peak at around $256 \mathrm{~nm}$ and a negative peak at around $236 \mathrm{~nm}$, again as observed in previous studies reporting CD data for Gtriplex forming sequences in the presence of those two divalent cations. ${ }^{18}$ It has been argued that this spectral signature may in fact indicate the formation of a G-hairpin. ${ }^{8}$ This hypothesis is consistent with the CD profiles that we obtained during annealing and melting experiments performed with conjugate 1 (vide supra, Fig. S22). As expected, no define peaks could be observed in the absence of stabilizing cations. 
On the other hand, the CD spectra of 2 were characteristics of G4 architectures. ${ }^{20}$ As anticipated, 2 appears to fold into an antiparallel G4 structure in presence of $\mathrm{Na}^{+}$(as drawn in Fig. S21), as evidenced by the typical positives peaks at $240 \mathrm{~nm}$ and $290 \mathrm{~nm}$ and by the negative peak at 260 nm (Fig. 2B). Also as expected, the $\mathrm{CD}$ spectrum of 2 recorded in presence of $\mathrm{K}^{+}$suggests the formation of a hybrid-type G4 structure (as drawn in Fig. 1B). The same CD pattern was found in the presence of the divalent cations $\mathrm{Ca}^{2+}$ and $\mathrm{Mg}^{2+}$. Weak signals were observed in the absence of added cations suggesting that the template assembled G4 forming structure is not folded under those destabilizing conditions.

1 and 2 appear to display distinct signals and the concordance between their respective CD signals and those recorded for G3 and G4 in multiple previous reports support the formation of a G3 structure from conjugate $\mathbf{1}$ and G4 from 2.

To obtain further information about the topological structures within conjugates $\mathbf{1}$ and $\mathbf{2}$, we also collected their thermal absorbance difference spectra (TDS) according to reported procedure ${ }^{21}$ in the presence of $100 \mathrm{mM}$ of either $\mathrm{K}^{+}, \mathrm{Na}^{+}, \mathrm{Ca}^{2+}$, or $\mathrm{Mg}^{2+}$. Conjugate 2 showed typical $\mathrm{G} 4$ features in the presence of all four metal cations with two positive peaks, one at around $245 \mathrm{~nm}$ and the other at $271 \mathrm{~nm}$, as well as one negative peak at $295 \mathrm{~nm}$ (Fig. 3). On the other hand, 1 did not show those features as we observed a positive broad peak from $260 \mathrm{~nm}$ to $270 \mathrm{~nm}$ in all experimental conditions (Fig. 3). Those spectra differ in their global shape which, again, suggest the formation of distinct structures.

1 and 2 may constitute good model systems to study and compare the interactions of small molecule ligands with G-triplex and G-quadruplex, respectively. Before investigating such interactions using BLI technique, we first wanted to define the thermal stabilities of the folded structures within buffer conditions that would be BLI-compatible and relevant to physiological 
conditions. The melting and annealing of the DNA structures formed by $\mathbf{1}$ and $\mathbf{2}$ were thus recorded in presence of $100 \mathrm{mM}$ potassium cations.

$\mathrm{CD}$ denaturation studies showed that the melting temperature of the G4 formed by the conjugate 2 was $70^{\circ} \mathrm{C}$ (Fig. S23). On the other hand, while monitoring the thermal unfolding of the Gtriplex formed by $\mathbf{1}$ we uncovered two distinct transitions suggesting the formation of an intermediate structure. A first structural modification is evidenced at $290 \mathrm{~nm}$ with a $\mathrm{Tm}$ of $50^{\circ} \mathrm{C}$ followed by the complete unfolding evidenced at $260 \mathrm{~nm}$ with a $\mathrm{Tm}$ of $70^{\circ} \mathrm{C}$ (Fig. S22). We hypothesized that partial unfolding of the G-triplex lead to the formation of a transient antiparallel G-hairpin structure. This hypothesis is consistent with the predicted unfolding process of the G-triplex. ${ }^{6 c}$ Furthermore, the CD spectrum obtained between the two melting temperatures (positive peak at $260 \mathrm{~nm}$ ) is comparable to those obtained for G-hairpin structures reported in the literature. , $^{10 a}$ Those spectra are also comparable to those obtained for the conjugate 1 in presence of $\mathrm{Ca}^{2+}$ and $\mathrm{Mg}^{2+}$ which might suggest the prevalent stabilization of the G-hairpin structure in the presence of those two divalent cations, again as emphasized in previous studies. ${ }^{9}$ In addition, while there were no difference between the CD melting and folding profiles at $260 \mathrm{~nm}$ at the heating rate of $0.5^{\circ} \mathrm{C} / \mathrm{min}$, the $\mathrm{CD}$ melting and annealing profiles of 1 showed a considerable hysteresis at $290 \mathrm{~nm}$ (Fig. S22). This suggests slow kinetics for the folding of the Gtriplex within conjugate 1. Under CD monitoring we could indeed observe the slow rate of reassociation as it takes nearly 7 hours for the CD signal the reverse to its initial profile (Fig. 4). Lastly, and prior to performing binding studies, we also confirmed that the unfolding process was independent of the molecular concentration (Fig. S24). This was evidenced by homogeneous melting temperatures at various concentration (at both $260 \mathrm{~nm}$ and $290 \mathrm{~nm}$ ) and endorsed the formation of an intramolecular G3 triplex within conjugate $\mathbf{1 .}$ 
Regardless of the folding process, the CD melting studies demonstrate that the G3 and G4 structures formed by $\mathbf{1}$ and $\mathbf{2}$ respectively are stable at and above room temperature in the presence of $100 \mathrm{mM} \mathrm{KCl}$ opening the way to the use of those molecular objects to investigate the interactions of G3 and G4 with small synthetic binding ligands.

\section{BLI binding assays}

As mentioned above there are only two reports of small molecules interacting with G3 structures. In both cases the putative G3 ligands were also shown to interact with distinct high order DNA structures in the form of G4.

To better explore the propensity of broadly used G4 binding ligands to interact with the G3 structure formed by conjugate 1, we collected four compounds, and compared, by BLI, their interactions with the G3 structure 1, the G4 structure 2 and a hairpin DNA control 8 (Fig. S25) (Table 1). Template assembled G4 structures similar to $\mathbf{2}$ and hairpin DNA such as $\mathbf{8}$ have been successfully used in our group to probe the interactions of G4 binding ligands with G4 and duplex architectures using SPR. ${ }^{22}$ We have recently shown that similar studies could be performed using BLI. ${ }^{23}$ In the present study, we investigated the interactions of TMPyP4, BRACO-19, PDS, and PhenDC3 (Fig. 5) with conjugates 1, 2 and 8. TMPyP4 is a porphyrin which has been repeatedly shown to interact with G4 structures but which is also known to interact with duplex DNA. ${ }^{24}$ BRACO-19 is an acridine derivative that has been shown to interact with telomeric G4 within cells. ${ }^{25}$ PDS and PhenDC3 are strong stabilizer of G4 structures that have been used to promote the formation of G4 in vitro and to probe the formation of G4 structures within cells. ${ }^{26}$ To perform the BLI binding analysis, streptravidin-coated biosensors were dipped in solution of conjugates 1, 2 and $\mathbf{8}$ in HEPES buffer containing $150 \mathrm{mM} \mathrm{KCl}$ until similar immobilization levels were obtained. The functionalized sensors were then dipped in 
increasing concentrations of the G4 ligands in presence of $150 \mathrm{mM} \mathrm{KCl}$ (Table S1). The sensorgrams were recorded (Fig. S27-S30) and the thermodynamic dissociation constant values $\left(\mathrm{K}_{\mathrm{D}}\right)$ were calculated from the kinetic parameters of the interactions. The association/dissociations rates $\left(\mathrm{k}_{\mathrm{on}} / \mathrm{k}_{\text {off }}\right)$ and the dissociation constants are reported in Table 1. To compare the kinetic nature of the interactions, the association/dissociation rates are plotted on a logarithmic scale on Figure S26.

In agreement with previous reports, we found that TMPyP4 displays no selectivity for the G4 structure over the hairpin DNA. Remarkably, we found that the affinity of TMPyP4 for the G3 structure 1 is slightly higher ( $\sim 2$ folds) than for the telomeric G4 structure 2. The similar $K_{D}$ collected with TMPyP4 for the recognition of $\mathbf{1}$ and $\mathbf{2}$ could be explained by the binding mode of TMPyP4 which possess a large surface which interact via $\pi-\pi$ stacking with the external G-tetrad but which could similarly interact with a G-triad. Although all three other ligands could better discriminate between higher order structures (G3 and G4) versus DNA hairpin, again, none were found to distinguish between the G3 and the G4 structures. The dissociation constants obtained for the interactions of those three ligands with the G4 structure 2 were consistent with reported values of three-digit nanomolar for BRACO-19, two-digit nanomolar for PDS and low nanomolar for PhenDC3. ${ }^{16}$ Yet in all cases, the dissociation constant obtained for the interactions with the G3 structure 1 were found to be similar or somewhat lower to that obtained with the G4 structure. Furthermore, we found that all the ligands display comparable association and dissociation rates while binding to the G3 or G4 structure (Table 1 and Figure S26). To further confirm that the selective high affinity interactions of PDS and PhenDC3 toward the G3 and G4 structures were the consequence of structural recognition, we also recorded the sensorgrams as those two ligands were incubated with the conjugates $\mathbf{1}$ and $\mathbf{2}$ in absence of stabilizing potassium cations. As 
anticipated from the CD experiments which shows that the G3 and G4 are not folded within $\mathbf{1}$ and $\mathbf{2}$ in the absence of potassium, we did not observe any binding signals.

To further support the observed binding promiscuity, preliminary SPR experiments were also carried out to assess the interactions between the highest affinity ligands PDS and PhenDC3 and the DNA structures 1, 2 and $\mathbf{8}$ (Fig. S31, Table S3). As expected and in perfect accordance with the BLI experiments, we observed identical binding affinities for each ligand toward the G3 and G4 structure and we did not observe interactions with the hairpin structure. The thermodynamic dissociation constant values obtained via SPR were on the order of one digit nanomolar for PhenDC3 and two digits nanomolar for PDS, again in agreement with the $\mathrm{K}_{\mathrm{D}}$ determined by BLI. Although the promiscuity of G4 binding ligands toward G3 structures could be suspected from previous reports, the current study indisputably shows that, despite differences in hydrophobic surfaces and groove organization and accessibility, some of the most prominent G4 binding ligands may bind to G3 structures with identical binding affinities. All four ligands have been widely used to study G4 biology and PDS and PhenDC3 have been exploited to profile and visualize DNA and RNA G4 structures in human cells. Regardless of the exact binding mode of those ligands with the G3 structure, these data highlight remarkable aspects of the interactions of G4 binding ligands with alternative nucleic acid structures that should encourage further investigations.

\section{Conclusion}

In summary, we have designed and synthesized two peptide-DNA conjugates capable of folding into stable G3 and G4 structures. Those structural mimics were used to probe the interactions between G4 binding ligands and a G3 structure and confirm previously suspected binding promiscuity. In the past years, G4 ligands have also been shown to interact with i-motif 
DNA structures. ${ }^{27}$ Our study, along with those previous reports, suggest that G4 targeting ligands may also regulate gene expression via alternative molecular mechanisms. Putative G3 forming sequences soundly outnumber putative G4 forming sequences and their dynamic regulation by endogenous proteins could be significant for genome stability. If so, controlling the formation of G3 structures via selective synthetic binding ligands could have therapeutic relevance. There has been only few attempts to develop G3 selective ligands and those efforts resulted in the identification of high affinity but nonspecific binders. This suggest that finding truly selective Gtriplex ligands is likely going to be a very challenging scientific objective. We anticipate that the structural mimic reported in this study will enable the medium-throughput evaluation and/or high-throughput selection of putative structure-specific G3 binding ligands. To provide further insights into G3 regulation pathways, we are also planning to use the mimic to pull-down and characterize G3 cellular protein partners. Efforts in those directions will be reported in due course.

\section{Experimental Section}

\section{General remark}

ESI mass spectra were performed on an Esquire 3000 spectrometer from Bruker or on an Acquity UPLC/MS system from Waters equipped with a SQ Detector 2. Peptides were analyzed in positive mode and oligonucleotides and conjugates in negative mode. All solvents and reagents used were of highest purity commercially available.

\section{Peptide synthesis}

\section{General details}


The synthesis was performed on a Syro II synthesizer using Fmoc/tBu strategy on a 2Chlorotrityl resin.

The course of reactions were monitored by using UPLC system Waters, it includes reverse phase chromatography using Nucleosil C18 column (130 A, 2.1 x $50 \mathrm{~mm}, 1.7 \mu \mathrm{m})$ and detection by UV at $214 \mathrm{~nm}$ and $250 \mathrm{~nm}$. A $1 \mathrm{~mL} / \mathrm{min}$ flow linear gradient from $95 \%$ solvent $\mathrm{A}(0.1 \%$ formic acid in water) and 5\% solvent B (0.1\% formic acid in acetonitrile/water: $9 / 1)$ to $100 \%$ B for 3 minutes was applied.

RP-HPLC purifications were performed on a Gilson system with Nucleosil C18 column (100 A, $250 \times 21 \mathrm{~mm}, 7 \mu \mathrm{m})$ with UV monitoring at $214 \mathrm{~nm}$ and $250 \mathrm{~nm}$. A $20 \mathrm{~mL} / \mathrm{min}$ flow linear gradient was applied from 95\% solvent A (0.1\% trifluoroacetic acid in water) and 5\% solvent B (0.1\% trifluoroacetic acid in acetonitrile/water: $9 / 1)$ to $100 \%$ B for 20 minutes.

\section{Synthesis of peptide 3}

The synthesis is described in details in the supporting information (scheme S1). The linear peptide was synthesized using commercially available 2-Chlorotrityl resin (loading of 0.83 mmol/g). Fmoc-Gly-OH (3 eq) was coupled on the resin in anhydrous DCM in a glass reaction vessel fitted with a sintered glass. $\mathrm{pH} 8$ was adjusted using DIEA. The mixture was stirred for $1 \mathrm{~h}$ at room temperature. A DCM/MeOH/DIEA solution (17:2:1, v:v:v) was then added. Fmoc protecting group was removed using three washes with $20 \%$ piperidine in DMF $(40 \mathrm{~mL})$. The resin loading was monitored by quantification of free dibenzofulvene using UV absorbance at $299 \mathrm{~nm}$ (loading of $0.40 \mathrm{mmol} / \mathrm{g}$, yield: 48\%). The elongation was performed on a Syro II using Fmoc/tBu strategy on the above-prepared resin, Fmoc-Ala-OH, Fmoc-Gly-OH, FmocLys(Alloc)-OH, Fmoc-Lys(Dde)-OH, Fmoc-Pro-OH and Fmoc-Lys(biotin)-OH were 
commercially available. Fmoc-azidononorleucine and Fmoc-Lys(-CO-CH $2-\mathrm{O}-\mathrm{N}=\mathrm{Eei})-\mathrm{OH}$ were obtained using reported protocols. The linear peptide was cleaved from the resin using a DCM/TFE/AcOH solution $(70 / 20 / 10, \mathrm{v} / \mathrm{v} / \mathrm{v})(5 \mathrm{x} 20 \mathrm{~mL})$. The solution was evaporated under vacuum and the peptide was precipitated in ether as a white powder. The crude product was used without any further purification. The cyclisation of the linear peptide (365 $\mathrm{mg}$ ) was performed in DMF at $10^{-3} \mathrm{M}$ concentration in presence of 1.2 eq of PyBOP $(0.250 \mathrm{mmol}, 130 \mathrm{mg})$. The $\mathrm{pH}$ was adjusted to 8-9 using DIEA and the solution was stirred at room temperature until the complete peptide cyclisation (UPLC monitoring). The solvent was evaporated under vacuum then the crude peptide was precipitated in ether. The crude product was purified on RP-HPLC and freeze-dried to obtain a white powder $(0.15 \mathrm{mmol}, 238 \mathrm{mg}$, yield: $66 \%$ for two steps $) . \mathrm{Rt}=1.86$ min. ESI-MS (+): $m / z$ calcd for $\mathrm{C}_{77} \mathrm{H}_{123} \mathrm{~N}_{20} \mathrm{O}_{19} \mathrm{~S}: 1663.8, \mathrm{~m} / z$ found: $1664.6[\mathrm{M}+\mathrm{H}]^{+}$. The DDE protecting group was then removed using a $2 \%$ hydrazine solution in DMF in presence of 20 eq. of allylic alcohol. The solution was stirred at room temperature until the complete deprotection (UPLC monitoring). The solvent was evaporated under vacuum then the crude peptide was precipitated in ether as a white powder. The crude product was used without any further purification. The peptide was next functionalized using 2 equiv of chloroacetic anhydride in DMF $\left(3.10^{-3} \mathrm{M}\right)$ at $\mathrm{pH} 8-9$. The reaction was stirred for $1 \mathrm{~h} 30$ at room temperature. The solvent was evaporated under vacuum then the crude peptide was precipitated in ether. The crude product was purified on RP-HPLC and freeze-dried to obtain a white powder (0.09 mmol, $142 \mathrm{mg}$, yield: $60 \%$ for two steps). Rt $=1.74$ min. ESI-MS $(+): m / z$ calcd for $\mathrm{C}_{69} \mathrm{H}_{112} \mathrm{ClN}_{20} \mathrm{O}_{18} \mathrm{~S}: 1575.8, \mathrm{~m} / z$ found: $1576.5[\mathrm{M}+\mathrm{H}]^{+}$. Peptide 3 was obtained after oxyamine deprotection by using a TFA/ $\mathrm{H}_{2} \mathrm{O} / \mathrm{TIS}(80 / 16 / 4, \mathrm{v} / \mathrm{v} / \mathrm{v})$ solution $(4 \mathrm{~mL})$ for $2 \mathrm{~h}$ at room temperature. The solvent was evaporated under vacuum then the crude peptide was precipitated in ether as a white powder. The crude product was used without any further purification. The yield was considered as 
quantitative. $\mathrm{Rt}=1.42$ min. ESI-MS $(+): \mathrm{m} / z$ calcd for $\mathrm{C}_{65} \mathrm{H}_{106} \mathrm{ClN}_{20} \mathrm{O}_{17} \mathrm{~S}: 1507.1, \mathrm{~m} / z$ found: $1506.5[\mathrm{M}+\mathrm{H}]^{+}$.

\section{Oligonucleotide synthesis}

\section{General details}

Oligonucleotides were prepared using $\beta$-cyanoethylphosphoramidite chemistry on a 3400 DNA synthesizer at $1 \mu \mathrm{mol}$ scale.

RP-HPLC analyses were performed on a Waters HPLC system using C18 Nucleosil column (Macherey-Nagel, $100 \AA \AA, 250 \times 4.6 \mathrm{~mm}, 5 \mu \mathrm{m}$ ) with UV-monitoring at $260 \mathrm{~nm}$ and $280 \mathrm{~nm}$. A 1 $\mathrm{mL} / \mathrm{min}$ flow linear gradient was applied. Solvent A $(50 \mathrm{mM}$ triethylammonium acetate buffer with 5\% acetonitrile) and solvent B (acetonitrile with 5\% water) were used. A stepwise gradient of $0-30 \% \mathrm{~B}$ in $20 \mathrm{~min}$ then from 30 to $100 \% \mathrm{~B}$ in 10 min was applied for the gradient. The RPHPLC purifications of oligonucleotides were performed on a Gilson system with Nucleosil C-18 colunm (Macherey-Nagel, $100 \AA$, 250 x $10 \mathrm{~mm}, 7 \mu \mathrm{m}$ ) with UV-monitoring at $260 \mathrm{~nm}$ and 280 $\mathrm{nm}$ using $4 \mathrm{~mL} / \mathrm{min}$ flow linear gradient. A stepwise gradient of 0-30\% B in 20 min then from 30 to $100 \% \mathrm{~B}$ in 10 min was applied.

Desalting of oligonucleotides was performed by SEC on NAP 25 cartridge using manufacturer's protocol.

Quantification of oligonucleotides was performed at $260 \mathrm{~nm}$ using Nanodrop apparatus (molar extinction $\varepsilon 260 \mathrm{~nm}$ was estimated according to the nearest neighbor model).

\section{Synthesis of oligonucleotide 4}


The oligonucleotide 4 was obtained from automated synthesis on a 3'-glyceryl CPG resin at 1 $\mu$ mol scale using a 3400 DNA synthesizer from Applied Biosystems (scheme S2). The last coupling was carried using commercially available 5 ' hexynyl ( $\beta$-cyanoethyl) phosphoramidite (GlenReseach). After synthesis, cyanoethyl protecting groups were removed using 20\% piperidine in acetonitrile. Cleavage from the resin and deprotection was performed in $28 \%$ $\mathrm{NH}_{4} \mathrm{OH}$ for $16 \mathrm{~h}$ at $55^{\circ} \mathrm{C}$. The product was purified on RP-HPLC and readily oxidized toward oligonucleotide 4. Sodium metaperiodate (20 eq; $8 \mu \mathrm{mol} ; 1.7 \mathrm{mg}$ ) was added to 1 eq (400 nmol) of purified product in water $(400 \mu \mathrm{L})$. The reaction was stirred for $1 \mathrm{~h}$ at room temperature in dark conditions. The product was then desalted on NAP 25 and the fractions were collected to obtain the crude product (UV-monitored at $260 \mathrm{~nm}$ ). The oxidation was considered quantitative and the crude containing oligonucleotide 4 was used in the next step without further purification. The purity of the crude material was assessed by ESI-MS and RP-HPLC. Rt $=14.8$ min, ESI-MS (-) $m / z$ calcd for $\mathrm{C}_{118} \mathrm{H}_{147} \mathrm{~N}_{46} \mathrm{O}_{72} \mathrm{P}_{12}: 3733.4, m / z$ found: 3733.3 [M-H]-

\section{Synthesis of oligonucleotide 5}

The oligonucleotide 5 was obtained from automated synthesis on a 3'-thiol-modifier C3 S-S CPG resin at $1 \mu \mathrm{mol}$ scale using a 3400 DNA synthesizer from Applied Biosystems (scheme S3). After synthesis, cyanoethyl protecting groups were removed using $20 \%$ piperidine in acetonitrile. Cleavage from the resin and deprotection was performed in $28 \% \mathrm{NH} 4 \mathrm{OH}$ for $16 \mathrm{~h}$ at $55^{\circ} \mathrm{C}$. The product was purified on RP-HPLC and the DMT protecting groups was removed using in $80 \%$ aqueous acetic acid solution for $20 \mathrm{~min}$ at room temperature. After concentration of the acetic acid solution, dithiothreitol (100 eq) was added to a solution of the 3'SSOH oligonucleotide (500 nmoles) in Tris. $\mathrm{HCl}$ buffer $1 \mathrm{M}, \mathrm{pH} 8.5(500 \mathrm{uL})$. The mixture was stirred for $1 \mathrm{~h}$ at room 
temperature. The product was purified on RP-HPLC then desalted and freeze-dried. $\mathrm{Rt}=15.9$ min, ESI-MS (-) $m / z$ calcd for $\mathrm{C}_{63} \mathrm{H}_{81} \mathrm{~N}_{24} \mathrm{O}_{38} \mathrm{P}_{6} \mathrm{~S}: 2000.4, m / z$ found: $1999.9[\mathrm{M}-\mathrm{H}]^{-}$.

\section{Synthesis of oligonucleotide 6}

Oligonucleotide 6 was obtained from automated synthesis on a 3'-thiol-modifier C3 S-S CPG resin at $1 \mu \mathrm{mol}$ scale using a 3400 DNA synthesizer from Applied Biosystems (scheme S3). After synthesis, cyanoethyl protecting groups were removed using $20 \%$ piperidine in acetonitrile. Cleavage from the resin and deprotection was performed in $28 \% \mathrm{NH} 4 \mathrm{OH}$ for $16 \mathrm{~h}$ at $55^{\circ} \mathrm{C}$. The product was purified on RP-HPLC and the DMT protecting groups was removed using in $80 \%$ aqueous acetic acid solution for $20 \mathrm{~min}$ at room temperature. After concentration of the acetic acid solution, dithiothreitol (100 eq) was added to a solution of the 3'SSOH oligonucleotide (400 nmoles) in Tris. $\mathrm{HCl}$ buffer $1 \mathrm{M}, \mathrm{pH} 8.5(400 \mathrm{uL})$. The mixture was stirred for $1 \mathrm{~h}$ at room temperature. The product was purified on RP-HPLC then desalted and freeze-dried. Rt $=15.9$ min, ESI-MS (-) $m / z$ calcd for $\mathrm{C}_{113} \mathrm{H}_{142} \mathrm{~N}_{46} \mathrm{O}_{68} \mathrm{P}_{11} \mathrm{~S}: 3605.4, \mathrm{~m} / z$ found: $3605.4[\mathrm{M}-\mathrm{H}]^{-}$.

\section{Conjugate synthesis}

\section{Synthesis of conjugate 7}

The synthesis is described in details in the supporting information (scheme S4). Briefly, 3' aldehyde containing oligonucleotide 4 ( 1 eq, 490 nmoles) was dissolved in $0.4 \mathrm{M}$ ammonium acetate buffer ( $\mathrm{pH} 4.5$, concentration $10^{-3} \mathrm{M}$ ) and aminooxy peptide 3 (1.2 eq, $588 \mathrm{nmoles}$ ) was added. The solution was stirred at $55^{\circ} \mathrm{C}$ for $45 \mathrm{~min}$. The crude was purified using RP-HPLC, desalted by SEC and freeze dried. Quantification was performed by UV-spectrometry (294 nmoles, yield $\left.60 \%, \varepsilon_{260} \mathrm{~nm}=114800 \mathrm{M}^{-1} \cdot \mathrm{cm}^{-1}\right) . \mathrm{Rt}=22.2 \mathrm{~min}$. ESI-MS $(-) \mathrm{m} / \mathrm{z}$ calcd for $\mathrm{C}_{183} \mathrm{H}_{250} \mathrm{~N}_{66} \mathrm{O}_{88} \mathrm{P}_{12} \mathrm{SCl}: 5221.5, \mathrm{~m} / \mathrm{z}$ found: 5221.4 [M-H]-. The resulting conjugate (237 nmoles) 
was dissolved in $100 \mathrm{mM}$ HEPES buffer ( $\mathrm{pH} 7.4$, concentration 10-4 M) in presence of 10\% DMF (v,v), CuSO4 (6 eq by azido function), THPTA (30 eq by azido function) and sodium ascorbate (30 eq by azido function) were added. The reaction was stirred at $37^{\circ} \mathrm{C}$ for $2 \mathrm{~h}$ and quenched with $0.5 \mathrm{M}$ EDTA solution (50 eq by azido function). The resulting mixture was desalting by SEC. The crude was purified using RP-HPLC then conjugate 7 was desalted by SEC and freeze dried. Quantification was performed by UV-spectrometry (156 nmoles, yield 66\%, $\varepsilon 260 \mathrm{~nm}=114800$ M-1.cm-1). Rt $=19.5 \mathrm{~min}$. ESI-MS (-) $\mathrm{m} / \mathrm{z}$ calcd for C183H250N66O88P12SCl: 5221.5, m/z found: 5221.4 [M-H]-.

\section{Synthesis of conjugate 1}

Conjugate 7 (1 eq, $50 \mathrm{nmol})$ and oligonucleotide 5 (2 eq, $100 \mathrm{nmol})$ were dissolved in $\mathrm{H}_{2} \mathrm{O} / \mathrm{CH}_{3} \mathrm{CN}$ solution (9/1, v/v, concentration $5.10^{-4} \mathrm{M}$ ) and TCEP (2 eq by thiol function), 500 $\mathrm{mM} \mathrm{KCl}$, DIEA (45 eq by chloroacetamide function to obtain $\mathrm{pH} 8.5$ ), KI (60 eq by chloroacetamide function) were added. The reaction mixture was stirred at room temperature for 5h. The crude was purified using RP-HPLC then conjugate 1 was desalted by SEC and freeze dried. Quantification was performed by UV-spectrometry $\left(25 \mathrm{nmol}\right.$, yield $50 \%, \varepsilon_{260 \mathrm{~nm}}=176500$ $\left.\mathrm{M}^{-1} \cdot \mathrm{cm}^{-1}\right) . \mathrm{Rt}=17.8 \mathrm{~min}$. ESI-MS (-) $\mathrm{m} / \mathrm{z}$ calcd for $\mathrm{C}_{246} \mathrm{H}_{329} \mathrm{~N}_{90} \mathrm{O}_{126} \mathrm{P}_{18} \mathrm{~S}_{2}: 7184.4, \mathrm{~m} / \mathrm{z}$ found: $7186.7[\mathrm{M}-\mathrm{H}]^{-}$.

\section{Synthesis of conjugate 2}

Conjugate 7 (1 eq, $50 \mathrm{nmol})$ and oligonucleotide 6 (2 eq, $100 \mathrm{nmol})$ were dissolved in $\mathrm{H}_{2} \mathrm{O} / \mathrm{CH}_{3} \mathrm{CN}$ solution (9/1, v/v, concentration $5.10^{-4} \mathrm{M}$ ) and TCEP (2 eq by thiol function), 500 $\mathrm{mM} \mathrm{KCl}$, DIEA (45 eq by chloroacetamide function to obtain $\mathrm{pH} 8.5$ ), KI (60 eq by chloroacetamide function) were added. The reaction mixture was stirred at room temperature for 
5h. The crude was purified using RP-HPLC then conjugate 2 was desalted by SEC and freeze dried. Quantification was performed by UV-spectrometry $\left(30 \mathrm{nmol}\right.$, yield $60 \%, \varepsilon_{260 \mathrm{~nm}}=229600$ $\left.\mathrm{M}^{-1} \cdot \mathrm{cm}^{-1}\right) . \mathrm{Rt}=17.1 \mathrm{~min}$. ESI-MS (-) $\mathrm{m} / \mathrm{z}$ calcd for $\mathrm{C}_{296} \mathrm{H}_{390} \mathrm{~N}_{112} \mathrm{O}_{156} \mathrm{P}_{23} \mathrm{~S}_{2}: 8789.4$, m/z found: $8792.1[\mathrm{M}-\mathrm{H}]^{-}$.

\section{Circular dichroism and thermal denaturation studies}

Circular dichroism studies were performed after thoroughly desalting the products by SEC on NAP 25 cartridge. An annealing step was applied by heating the sample at $90^{\circ} \mathrm{C}$ for 5 min in buffer (Tris $10 \mathrm{mM}$ pH 7.4 with $100 \mathrm{mM} \mathrm{KCl}$ ) and cooling it over $2 \mathrm{~h}$ to room temperature. Analyses were recorded on a Jasco J-810 spectropolarimeter using $1 \mathrm{~cm}$ length quartz cuvette. Spectra were recorded at $20^{\circ} \mathrm{C}$ or every $5^{\circ} \mathrm{C}$ in a range from $5^{\circ} \mathrm{C}$ to $90^{\circ} \mathrm{C}$ with wavelengths range from 220 to $330 \mathrm{~nm}$. For each temperature, the spectrum was an average of three scans with a 0.5 s response time, a $1 \mathrm{~nm}$ data pitch, a $4 \mathrm{~nm}$ bandwidth and a $200 \mathrm{~nm} \cdot \mathrm{min}^{-1}$ scanning speed. Melting temperatures were obtained using Boltzmann fit on Origin software.

\section{Thermal difference spectrum (TDS)}

Thermal difference spectrum was obtained from the subtraction of UV spectrum performed at $5^{\circ} \mathrm{C}$ from UV spectrum performed at $90^{\circ} \mathrm{C}$. UV spectra were recorded on a Varian Cary $400 \mathrm{UV}$ visible spectrophotometer using $1 \mathrm{~cm}$ length quartz cuvette. Spectra were recorded at $5^{\circ} \mathrm{C}$ and $90^{\circ} \mathrm{C}$ with wavelengths range from 230 to $320 \mathrm{~nm}$. The difference spectra were normalized by dividing the raw data by its maximum value, so that the highest positive peak gets a $\mathrm{Y}$-value of +1 as recommended in reference 21 of the manuscript.

\section{BLI experiments}


Bio-layer interferometry experiments were performed using sensors coated with streptavidin (SA sensors) purchased from Forte Bio (PALL). Prior functionalization, they were washed for 10 minutes by incubation in "BLI-buffer" (HEPES buffer $10 \mathrm{mM}, \mathrm{KCl} 150 \mathrm{mM}$, pH 7.5 and $0.5 \%$ $\mathrm{v} / \mathrm{v}$ surfactant P20) to dissolve the sucrose layer. Then, the sensors were dipped for 15 minutes in solutions containing the conjugates $\mathbf{1 , 2}$ or $\mathbf{8}$ (Figure S25) at $100 \mathrm{nM}$ in the BLI-buffer and then by dipping in the BLI-buffer for 10 minutes. The functionalized sensors were then dipped in G4ligand (TMPyP4, Braco-19, PDS and PhenDC3) containing solution at different concentrations (Table S1) interspersed by a rinsing step in the buffer solution. The concentrations and association and dissociation time were optimized for each ligand (Table S1). For TMPyP4 and Braco-19 the same sensors were used for the 6 concentrations whereas for PDS and PhenDC3, one sensor was used for each concentration as we couldn't achieve full dissociation of those ligands. A reference sensor without DNA was used to subtract the non-specific adsorption on the SA layer. The sensorgrams were fitted using a 1:1 interaction model. The reported values are the means of representative independent experiments, and the errors provided are standard deviations from the mean. Each experiment was repeated at least two times.

\section{SPR experiments}

HS- $\left(\mathrm{CH}_{2}\right)_{11}-\mathrm{EG}_{6}$-Biotin was procured from Prochimia. All other chemical products were purchased from Sigma-Aldrich. Cleaning procedure of the gold sensor chips included UV-ozone treatment during 10 min followed by rinsing with MilliQ water and ethanol. The cleaned gold surfaces were then functionalized according to the following procedure. Firstly, mixed selfassembled monolayers (SAMs) were formed at room temperature by dipping overnight gold sensors in the thiol mixture: $80 \%$ HS- $\left(\mathrm{CH}_{2}\right)_{11}-\mathrm{EG}_{4}-\mathrm{OH}$ and $20 \% \mathrm{HS}-\left(\mathrm{CH}_{2}\right)_{11}-\mathrm{EG}_{6}$-Biotin $(1 \mathrm{mM}$ total thiol concentration in EtOH). After overnight adsorption, gold sensors were rinsed with 
ethanol and dried under nitrogen. The surface is then inserted in the BIAcore T200 device. All measurements were performed at $25^{\circ} \mathrm{C}$, using a running buffer (R.B.) composed of HEPES buffered saline: (HEPES buffer $10 \mathrm{mM}, \mathrm{KCl} 150 \mathrm{mM}, \mathrm{pH} 7.5$ and 0.5\% v/v surfactant P20. Streptavidin $(100 \mathrm{ng} / \mathrm{mL})$ was injected $(10 \mu \mathrm{L} / \mathrm{min})$ on the biotinylated SAM until saturation of the surface (around 2400 R.U.). The different systems 1, 2 and 8 were injected at $2 \mu \mathrm{L} / \mathrm{min}$ on streptavidin-coated SAM surfaces until surface saturation.

Binding experiments were conducted by injection at $80 \mu \mathrm{L} \cdot \mathrm{min}^{-1}$ of PDS and Phend-DC3 dissolved in R.B at five different concentrations using a single cycle kinetic method (SCK). A streptavidin surface, prepared as described below, was used as reference. Curves obtained on the reference surface were deduced from the curves recorded on the recognition one, allowing elimination of refractive index changes due to buffer effects. The binding rate constants of DNA/ligands interactions were calculated by a non-linear analysis of the association and dissociation curves using the SPR kinetic evaluation software BIAcore T200 evaluation Software. The data were fitted using a heterogeneous ligand model taking into account the possible heterogeneity of the ligand presentation. The association rate constants, $\mathrm{k}_{\mathrm{on} 1}$ and $\mathrm{k}_{\mathrm{on} 2}$, and the dissociation rate constants, $\mathrm{k}_{\mathrm{off} 1}$ and $\mathrm{k}_{\mathrm{off} 2}$ as well as the theoretical maximal response $\mathrm{R}_{\max 1}$ and $\mathrm{R}_{\max 2}$ of the two interactions were calculated. Finally, the equilibrium dissociation constants were obtained from the binding rate constants as $K_{D 1}=k_{o f f 1} / k_{\text {on1 }}$ and $K_{D 2}=k_{\text {off2 }} / k_{\text {on2 }}$ We reported the thermodynamic dissociation constants that were consistent between independent experiments and for which the theoretical maximum response $\left(\mathrm{R}_{\max }\right)$ is consistent with 1:1 interaction. We chose to not report the parameters for the second interaction that might involve non-stoichiometric binding and/or non-specific interactions. 


\section{Acknowledgements}

This work was supported by the Labex ARCANE (ANR-11-LABX-0003-01) and CBH-EUR-GS (ANR-17-EUR-0003). The Nanobio-ICMG platform (FR2607) is acknowledged for providing facilities for synthesis, purification of oligonucleotides and peptides, and BioLayer Interferometry measurements. We thank Mr. Hugues Bonnet for performing control BLI experiments.

\section{Conflicts of interest:}

There are no conflicts to declare

\section{Additional information:}

Electronic supplementary information (ESI) available: Full experimental details and characterisation.

\section{Notes and References}

1. Hansel-Hertsch, R.; Di Antonio, M.; Balasubramanian, S., DNA G-quadruplexes in the human genome: detection, functions and therapeutic potential. Nature reviews. Molecular cell biology 2017, 18 (5), 279-284.

2. Tian, T.; Chen, Y.-Q.; Wang, S.-R.; Zhou, X., G-Quadruplex: A Regulator of Gene Expression and Its Chemical Targeting. Chem Eur J 2018, 4 (6), 1314-1344.

3. Asamitsu, S.; Bando, T.; Sugiyama, H., Ligand Design to Acquire Specificity to Intended G-Quadruplex Structures. Chem Eur J 2019, 25 (2), 417-430.

4. Muller, S.; Rodriguez, R., G-quadruplex interacting small molecules and drugs: from bench toward bedside. Expert review of clinical pharmacology 2014, 7 (5), 663-79. 
5. (a) Gray, R. D.; Buscaglia, R.; Chaires, J. B., Populated intermediates in the thermal unfolding of the human telomeric quadruplex. J Am Chem Soc 2012, 134 (40), 16834-44; (b) Boncina, M.; Lah, J.; Prislan, I.; Vesnaver, G., Energetic basis of human telomeric DNA folding into G-quadruplex structures. J Am Chem Soc 2012, 134 (23), 9657-63.

6. (a) Mashimo, T.; Yagi, H.; Sannohe, Y.; Rajendran, A.; Sugiyama, H., Folding pathways of human telomeric type-1 and type-2 G-quadruplex structures. J Am Chem Soc 2010, 132 (42), 14910-8; (b) Mondal, S.; Bhat, J.; Jana, J.; Mukherjee, M.; Chatterjee, S., Reverse Watson-Crick G-G base pair in G-quadruplex formation. Mol Biosyst 2016, 12 (1), 18-22; (c) Stadlbauer, P.; Kuhrova, P.; Banas, P.; Koca, J.; Bussi, G.; Trantirek, L.; Otyepka, M.; Sponer, J., Hairpins participating in folding of human telomeric sequence quadruplexes studied by standard and T-REMD simulations. Nucleic Acids Res 2015, 43 (20), 9626-44.

7. Bessi, I.; Jonker, H. R.; Richter, C.; Schwalbe, H., Involvement of Long-Lived Intermediate States in the Complex Folding Pathway of the Human Telomeric G-Quadruplex. Angew Chem Int Ed Engl 2015, 54 (29), 8444-8.

8. Hou, X. M.; Fu, Y. B.; Wu, W. Q.; Wang, L.; Teng, F. Y.; Xie, P.; Wang, P. Y.; Xi, X. G., Involvement of Gtriplex and G-hairpin in the multi-pathway folding of human telomeric G-quadruplex. Nucleic Acids Res 2017, 45 (19), 11401-11412.

9. Rajendran, A.; Endo, M.; Hidaka, K.; Sugiyama, H., Direct and single-molecule visualization of the solution-state structures of G-hairpin and G-triplex intermediates. Angew Chem Int Ed Engl 2014, 53 (16), 4107-12.

10. (a) Gajarsky, M.; Zivkovic, M. L.; Stadlbauer, P.; Pagano, B.; Fiala, R.; Amato, J.; Tomaska, L.; Sponer, J.; Plavec, J.; Trantirek, L., Structure of a Stable G-Hairpin. J Am Chem Soc 2017, 139 (10), 3591-3594;

(b) Cerofolini, L.; Amato, J.; Giachetti, A.; Limongelli, V.; Novellino, E.; Parrinello, M.; Fragai, M.; Randazzo, A.; Luchinat, C., G-triplex structure and formation propensity. Nucleic Acids Res 2014, 42 (21), 13393-404.

11. Hou, X. M.; Wu, W. Q.; Duan, X. L.; Liu, N. N.; Li, H. H.; Fu, J.; Dou, S. X.; Li, M.; Xi, X. G., Molecular mechanism of G-quadruplex unwinding helicase: sequential and repetitive unfolding of $G$ quadruplex by Pif1 helicase. Biochem J 2015, 466 (1), 189-99.

12. Rajendran, A.; Endo, M.; Hidaka, K.; Teulade-Fichou, M. P.; Mergny, J. L.; Sugiyama, H., Small molecule binding to a G-hairpin and a G-triplex: a new insight into anticancer drug design targeting G-rich regions. Chem Commun (Camb) 2015, 51 (44), 9181-4.

13. Amato, J.; Pagano, A.; Cosconati, S.; Amendola, G.; Fotticchia, I.; laccarino, N.; Marinello, J.; De Magis, A.; Capranico, G.; Novellino, E.; Pagano, B.; Randazzo, A., Discovery of the first dual Gtriplex/G-quadruplex stabilizing compound: a new opportunity in the targeting of G-rich DNA structures? Biochimica et biophysica acta. General subjects 2017, 1861 (5 Pt B), 1271-1280.

14. (a) Prado, E.; Bonnat, L.; Bonnet, H.; Lavergne, T.; Van der Heyden, A.; Pratviel, G.; Dejeu, J.; Defrancq, E., Influence of the SPR Experimental Conditions on the G-Quadruplex DNA Recognition by Porphyrin Derivatives. Langmuir 2018, 34 (43), 13057-13064; (b) Murat, P.; Bonnet, R.; Van der Heyden, A.; Spinelli, N.; Labbe, P.; Monchaud, D.; Teulade-Fichou, M. P.; Dumy, P.; Defrancq, E., Template-assembled synthetic G-quadruplex (TASQ): a useful system for investigating the interactions of ligands with constrained quadruplex topologies. Chem Eur J 2010, 16 (20), 6106-14; (c) Murat, P.; Cressend, D.; Spinelli, N.; Van der Heyden, A.; Labbe, P.; Dumy, P.; Defrancq, E., A Novel Conformation ally Constrained Parallel G Quadruplex. Chembiochem 2008, 9 (16), 2588-2591.

15. (a) Bonnat, L.; Dejeu, J.; Bonnet, H.; Gennaro, B.; Jarjayes, O.; Thomas, F.; Lavergne, T.; Defrancq, E., Templated Formation of Discrete RNA and DNA:RNA Hybrid G-Quadruplexes and Their Interactions with Targeting Ligands. Chem Eur J 2016, 22 (9), 3139-47; (b) Bonnet, R.; Lavergne, T.; Gennaro, B.; Spinelli, N.; Defrancq, E., Construction of anti-parallel G-quadruplexes through sequential templated click. Chem Commun (Camb) 2015, 51 (23), 4850-3. 
16. Bonnat, L.; Bar, L.; Gennaro, B.; Bonnet, H.; Jarjayes, O.; Thomas, F.; Dejeu, J.; Defrancq, E.; Lavergne, T., Template-Mediated Stabilization of a DNA G-Quadruplex formed in the HIV-1 Promoter and Comparative Binding Studies. Chem Eur J 2017, 23 (23), 5602-5613.

17. Foillard, S.; Rasmussen, M. O.; Razkin, J.; Boturyn, D.; Dumy, P., 1-Ethoxyethylidene, a new group for the stepwise SPPS of aminooxyacetic acid containing peptides. J Org Chem 2008, 73 (3), 983-91.

18. Jiang, H. X.; Cui, Y.; Zhao, T.; Fu, H. W.; Koirala, D.; Punnoose, J. A.; Kong, D. M.; Mao, H., Divalent cations and molecular crowding buffers stabilize G-triplex at physiologically relevant temperatures. Scientific reports 2015, 5, 9255.

19. Lu, X. M.; Li, H.; You, J.; Li, W.; Wang, P. Y.; Li, M.; Dou, S. X.; Xi, X. G., Folding Dynamics of Parallel and Antiparallel G-Triplexes under the Influence of Proximal DNA. J Phys Chem B 2018, 122 (41), 9499-9506.

20. Randazzo, A.; Spada, G. P.; da Silva, M. W., Circular dichroism of quadruplex structures. Topics in current chemistry 2013, 330, 67-86.

21. Mergny, J. L.; Li, J.; Lacroix, L.; Amrane, S.; Chaires, J. B., Thermal difference spectra: a specific signature for nucleic acid structures. Nucleic Acids Res 2005, 33 (16), e138.

22. (a) Piraux, G.; Bar, L.; Abraham, M.; Lavergne, T.; Jamet, H.; Dejeu, J.; Marcelis, L.; Defrancq, E.; Elias, B., New Ruthenium-Based Probes for Selective G-Quadruplex Targeting. Chem Eur J 2017, 23 (49), 11872-11880; (b) Lecarme, L.; Prado, E.; De Rache, A.; Nicolau-Travers, M. L.; Gellon, G.; Dejeu, J.; Lavergne, T.; Jamet, H.; Gomez, D.; Mergny, J. L.; Defrancq, E.; Jarjayes, O.; Thomas, F., Efficient Inhibition of Telomerase by Nickel-Salophen Complexes. Chemmedchem 2016, 11 (11), 1133-6.

23. (a) Weynand, J.; Diman, A.; Abraham, M.; Marcelis, L.; Jamet, H.; Decottignies, A.; Dejeu, J.; Defrancq, E.; Elias, B., Towards the Development of Photo-Reactive Ruthenium(II) Complexes Targeting Telomeric G-Quadruplex DNA. Chem Eur J 2018, 24 (72), 19216-19227; (b) Weynand, J.; Bonnet, H.; Loiseau, F.; Ravanat, J.-L.; Dejeu, J.; Defrancq, E.; Elias, B., Targeting G-rich DNA Structures with Photo-Reactive bis-Cyclometalated Iridium(III) Complexes. Chem Eur J 2019 just accepted doi.org/10.1002/chem.201902183

24. (a) Romera, C.; Bombarde, O.; Bonnet, R.; Gomez, D.; Dumy, P.; Calsou, P.; Gwan, J. F.; Lin, J. H.; Defrancq, E.; Pratviel, G., Improvement of porphyrins for G-quadruplex DNA targeting. Biochimie 2011, 93 (8), 1310-7; (b) Martino, L.; Pagano, B.; Fotticchia, I.; Neidle, S.; Giancola, C., Shedding light on the interaction between TMPyP4 and human telomeric quadruplexes. J Phys Chem B 2009, 113 (44), 14779-86.

25. Incles, C. M.; Schultes, C. M.; Kempski, H.; Koehler, H.; Kelland, L. R.; Neidle, S., A G-quadruplex telomere targeting agent produces p16-associated senescence and chromosomal fusions in human prostate cancer cells. Mol Cancer Ther 2004, 3 (10), 1201-6.

26. (a) Rodriguez, R.; Miller, K. M.; Forment, J. V.; Bradshaw, C. R.; Nikan, M.; Britton, S.; Oelschlaegel, T.; Xhemalce, B.; Balasubramanian, S.; Jackson, S. P., Small-molecule-induced DNA damage identifies alternative DNA structures in human genes. Nat Chem Biol 2012, 8 (3), 301-10; (b) De Cian, A.; Delemos, E.; Mergny, J. L.; Teulade-Fichou, M. P.; Monchaud, D., Highly efficient G-quadruplex recognition by bisquinolinium compounds. J Am Chem Soc 2007, 129 (7), 1856-7.

27. Abdelhamid, M. A. S.; Gates, A. J.; Waller, Z. A. E., Destabilization of i-Motif DNA at Neutral pH by GQuadruplex Ligands. Biochemistry 2019, 58 (4), 245-249.

\section{Figures and schemes.}


A

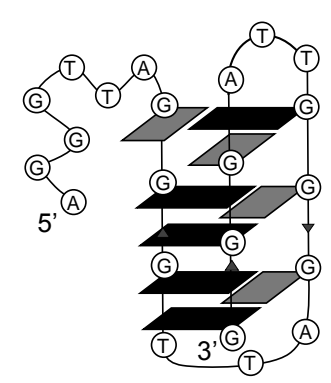

Tel-22 (G-triplex)

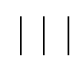

B

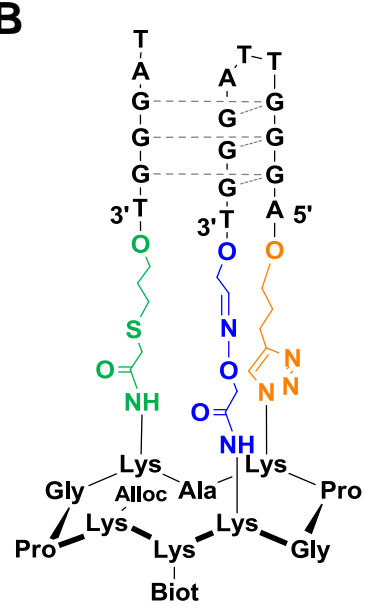

1

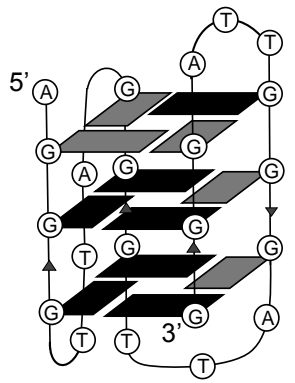

Tel-22 (G4 hybrid form)
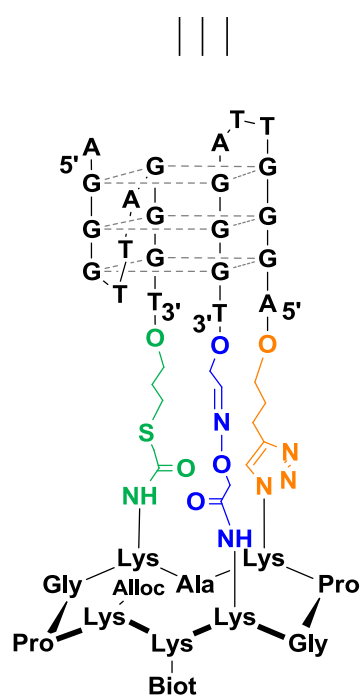

2

Fig 1. A/ Schematic drawing of putative G3 and G4 structures formed by the human telomeric DNA sequence (Tel-22) and corresponding G-tetrad arrangements (black box $=($ anti) guanine, grey box $=(s y n)$ guanine B/ G3 forming DNA conjugate $\mathbf{1}$ and G4 forming DNA conjugate $\mathbf{2}$ 
A
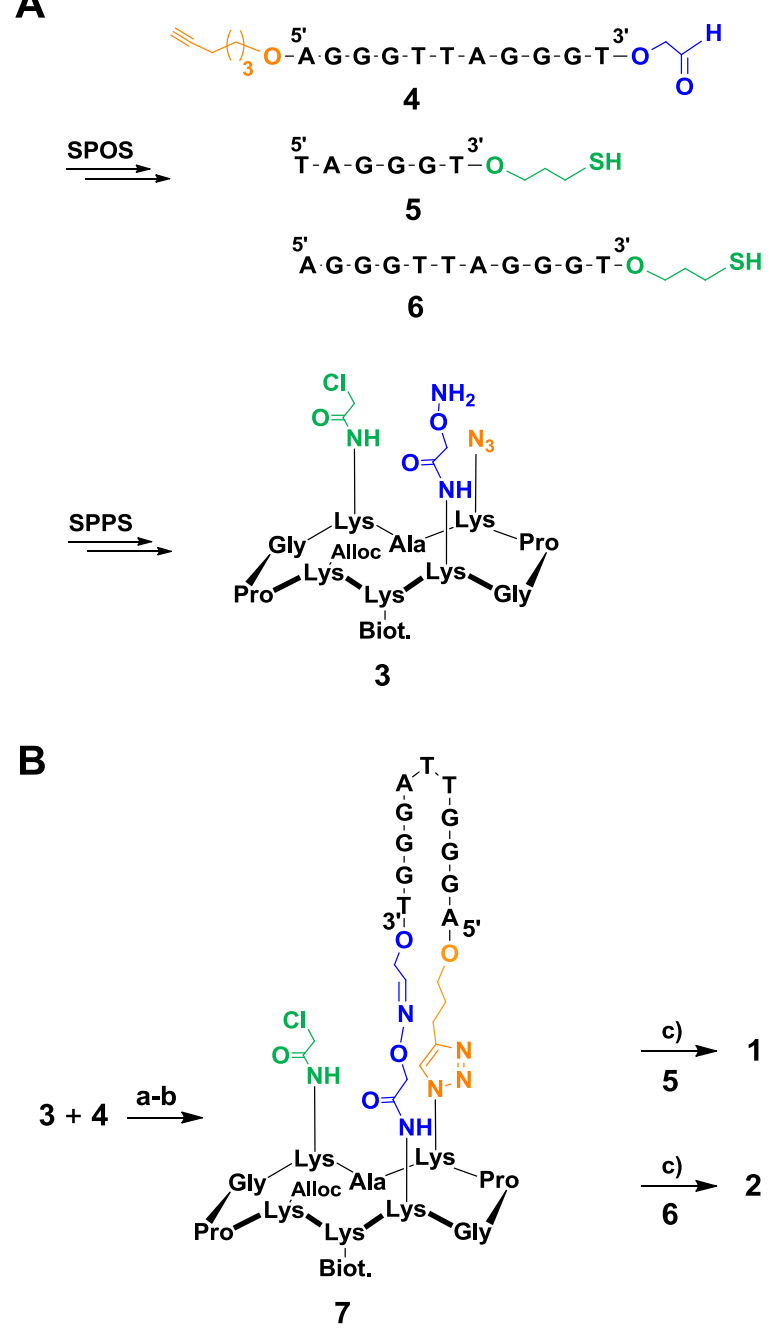

Scheme 1. A/ Oligonucleotide and peptide building blocks. B/ Assembly of conjugates 1 and 2. a) oligonucleotide 4 (1 equiv), peptide 3 (1.2equiv), $0.4 \mathrm{M}$ ammonium acetate buffer, $\mathrm{pH}$ 4.5, 45 min at $55^{\circ} \mathrm{C}$; b) HEPES $100 \mathrm{mM}, 10 \%$ DMF, CuSO4 (6 equiv), THPTA (30 equiv), sodium ascorbate (30 equiv), $\mathrm{pH} 7.4,2 \mathrm{~h}$ at $37^{\circ} \mathrm{C}$; c) oligonucleotide 5 or 6 ( 2 equiv), TCEP ( 2 equiv), DIEA (45 equiv), KI (60 equiv), $\mathrm{KCl} 500 \mathrm{mM}$, pH 8.5, under argon, $5 \mathrm{~h}$ at rt. 

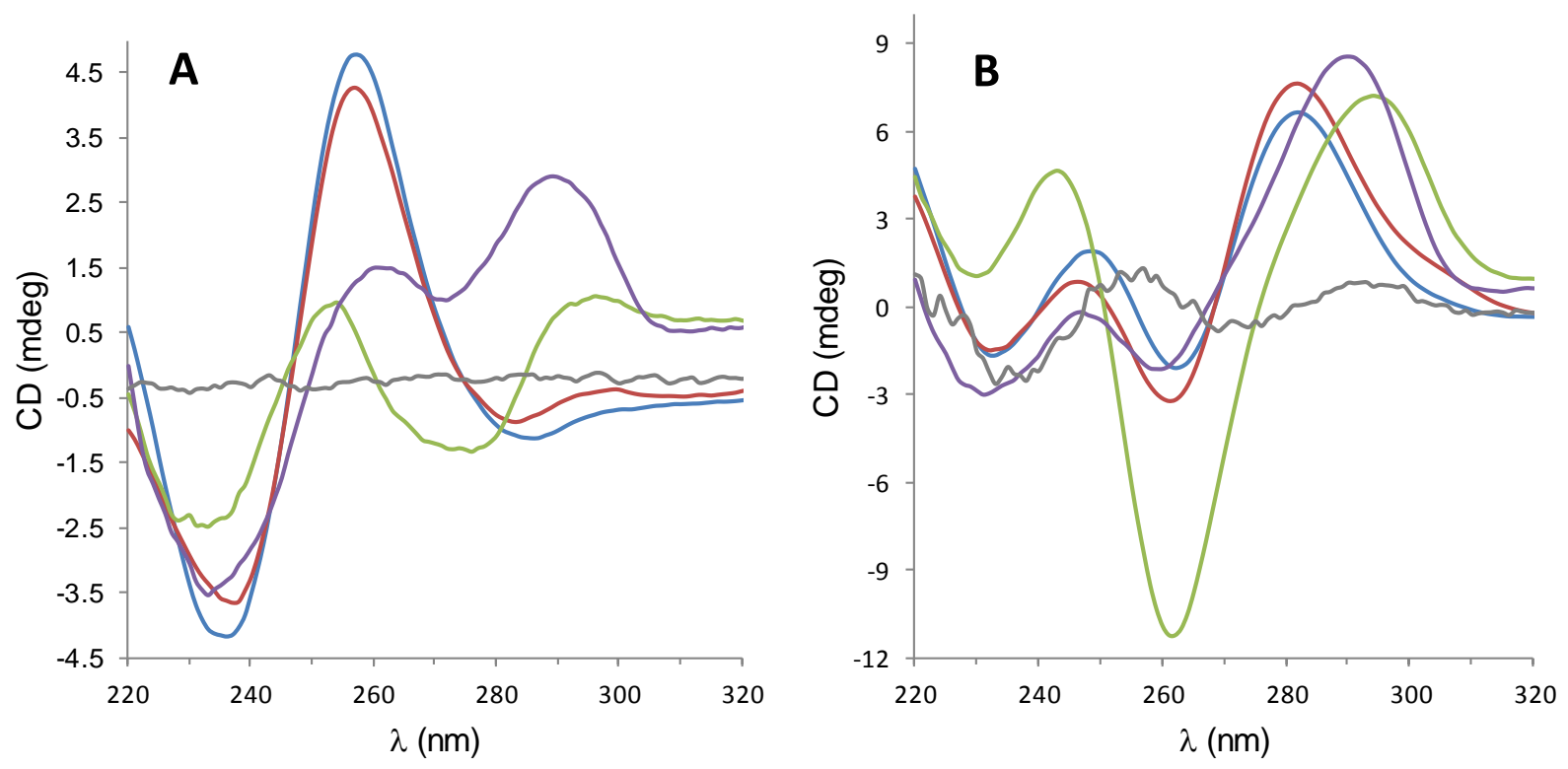

Fig. 2. CD spectra of G-triplex forming conjugate 1 (A) and G-quadruplex forming conjugate 2 (B) at $1.6 \mu \mathrm{M}$ in $10 \mathrm{mM}$ Tris- $\mathrm{HCl}, \mathrm{pH} 7.4,20^{\circ} \mathrm{C}$ in presence of $100 \mathrm{mM} \mathrm{KCl}$ (purple) or $100 \mathrm{mM}$ $\mathrm{NaCl}$ (green) or $100 \mathrm{mM} \mathrm{MgCl}_{2}$ (blue) or $100 \mathrm{mM} \mathrm{CaCl}_{2}$ (red) or in the absence of added cations (grey). 

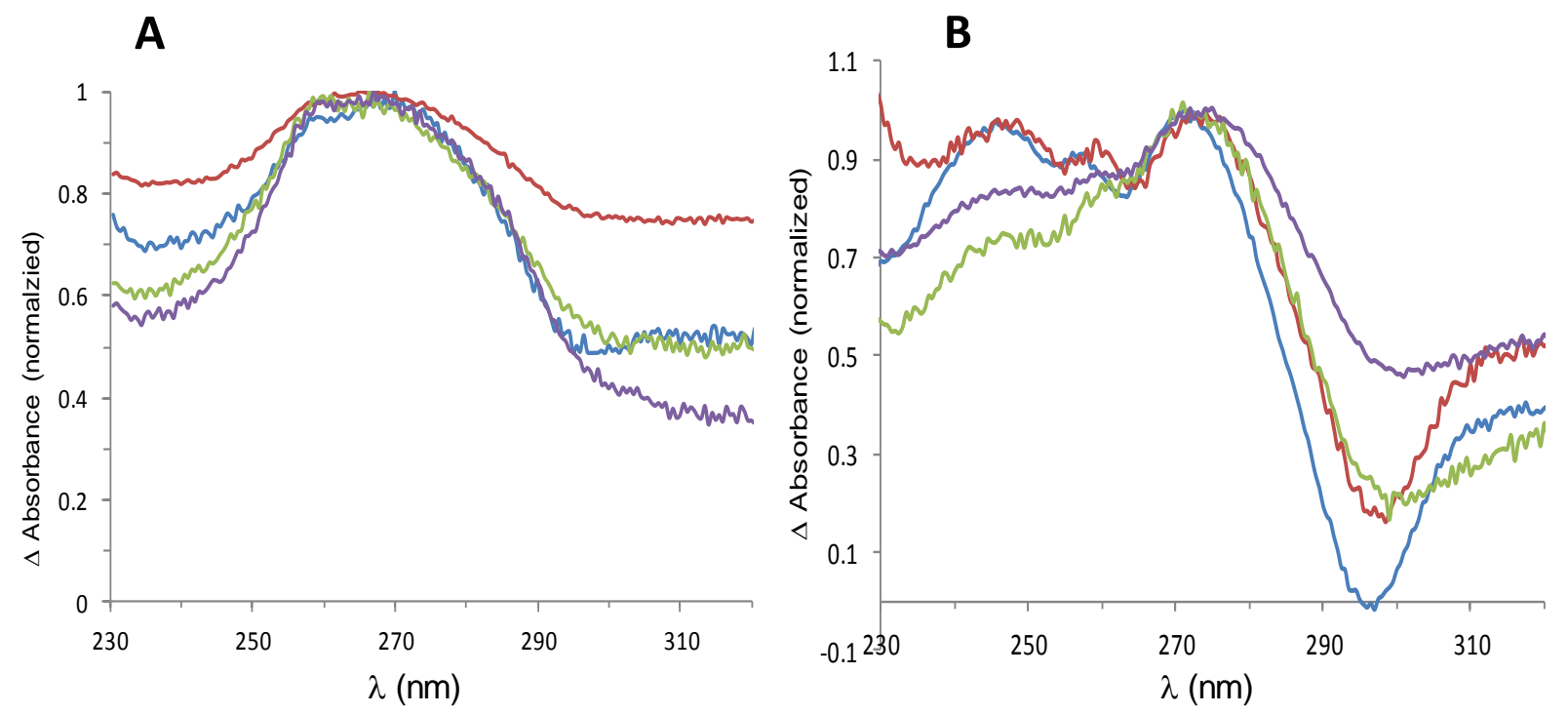

Fig. 3. Normalized thermal difference spectrum of conjugate $\mathbf{1}(\mathbf{A})$ and $\mathbf{2}(\mathbf{B})$ at $1.6 \mu \mathrm{M}$ in $10 \mathrm{mM}$ Tris- $\mathrm{HCl}, \mathrm{pH} 7.4,20^{\circ} \mathrm{C}$ in presence of $100 \mathrm{mM} \mathrm{NaCl}$ (red) or $100 \mathrm{mM} \mathrm{KCl}$ (blue) or $100 \mathrm{mM}$ $\mathrm{CaCl}_{2}$ (green) or $100 \mathrm{mM} \mathrm{MgCl} 2$ (purple). 


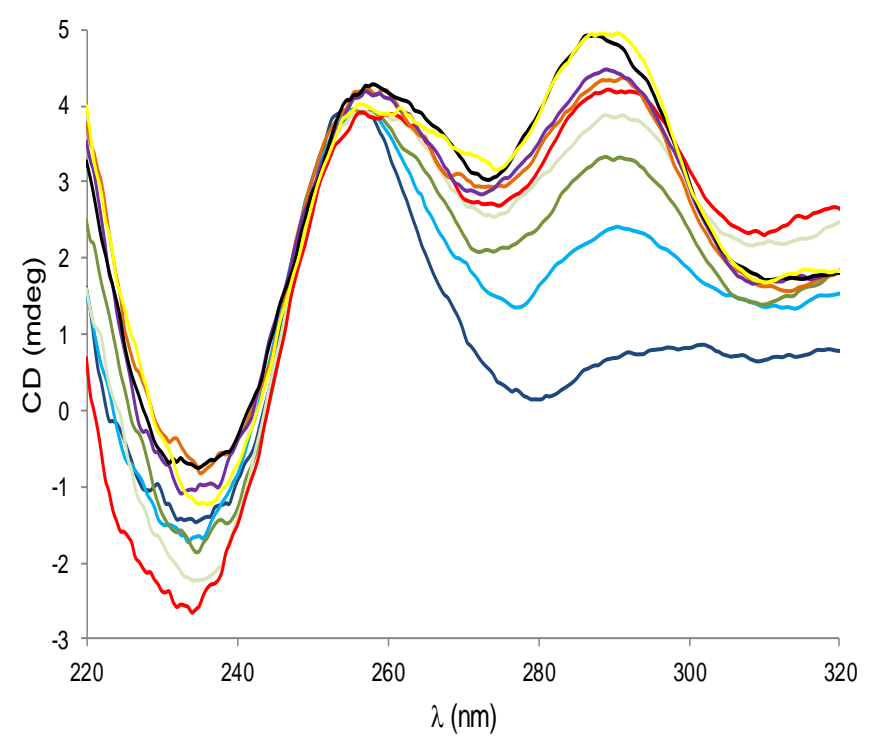

Fig. 4. $\mathrm{CD}$ spectra of conjugate 1 at $1.6 \mu \mathrm{M}$ in $10 \mathrm{mM}$ Tris- $\mathrm{HCl}, \mathrm{pH} 7.4,20^{\circ} \mathrm{C}$ after the addition of $\mathrm{KCl}(100 \mathrm{mM})$ at $1 \mathrm{~min}$ (blue), $1 \mathrm{~h}$ (teal), 2h (dark green), 3h (light green), 4h (red), $5 \mathrm{~h}$ (orange), 6h (purple), 7h (black), 8h (yellow).

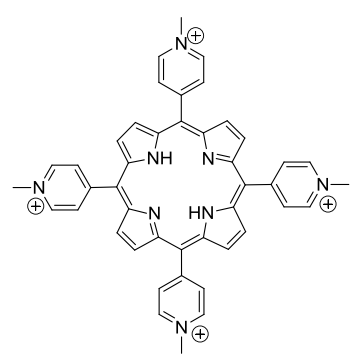

TMpyP4

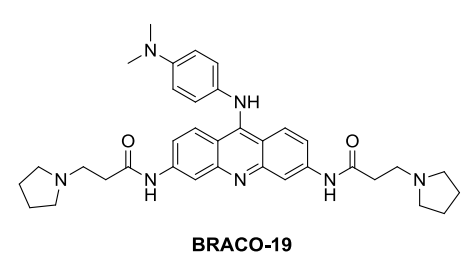

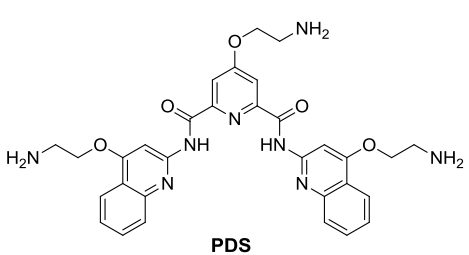

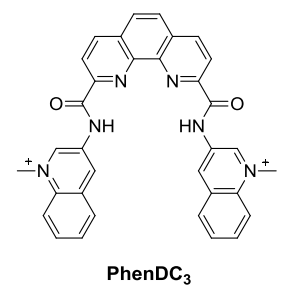

Fig. 5. Structure of the ligands subjected to BLI binding analysis 


\begin{tabular}{|c|c|c|c|c|c|c|c|c|c|}
\hline \multirow{3}{*}{ Ligands } & \multicolumn{3}{|c|}{ G3 structure 1 } & \multicolumn{3}{c|}{ G4 structure 2 } & \multicolumn{3}{c|}{ Hairpin structure 8 } \\
\cline { 2 - 11 } & $\mathrm{K}_{\text {on }}$ & $\mathrm{K}_{\text {off }}$ & $\mathrm{K}_{\mathrm{D}}$ & $\mathrm{k}_{\text {on }}$ & $\mathrm{k}_{\text {off }}$ & $\mathrm{K}_{\mathrm{D}}$ & $\mathrm{k}_{\text {on }}$ & $\mathrm{k}_{\text {off }}$ & $\mathrm{K}_{\mathrm{D}}$ \\
& $\left(\mathrm{M}^{-1} \mathrm{~s}^{-1}\right)$ & $\left(\mathrm{s}^{-1}\right)$ & $(\mathrm{nM})$ & $\left(\mathrm{M}^{-1} \mathrm{~s}^{-1}\right)$ & $\left(\mathrm{s}^{-1}\right)$ & $(\mathrm{nM})$ & $\left(\mathrm{M}^{-1} \mathrm{~s}^{-1}\right)$ & $\left(\mathrm{s}^{-1}\right)$ & $(\mathrm{nM})$ \\
\hline TMPyP4 & $1.9 \pm 0.1 .10^{5}$ & $2.6 \pm 0.2 .10^{-2}$ & $138 \pm 4$ & $1.5 \pm 0.1 .10^{5}$ & $3.7 \pm 0.8 .10^{-2}$ & $247 \pm 42$ & $1.7 \pm 0.1 .10^{5}$ & $1.9 \pm 0.0 .10^{-2}$ & $110 \pm 3$ \\
\hline Brac0 & $1.1 \pm 0.0 .10^{5}$ & $3.4 \pm 0.2 .10^{-2}$ & $318 \pm 10$ & $1.1 \pm 0.0 .10^{5}$ & $3.0 \pm 0.6 .10^{-2}$ & $288 \pm 43$ & $5.1 \pm 0.6 .10^{4}$ & $4.3 \pm 1.2 .10^{-2}$ & $823 \pm 140$ \\
\hline PDS & $2.9 \pm 1.2 .10^{4}$ & $9.4 \pm 0.5 .10^{-4}$ & $38 \pm 13$ & $2.4 \pm 0.1 .10^{4}$ & $2.2 \pm 0.2 .10^{-3}$ & $96 \pm 16$ & $n d$ & $n d$ & $n d$ \\
\hline PhenDC3 & $1.4 \pm 0.3 .10^{5}$ & $7.2 \pm 1.5 .10^{-4}$ & $5 \pm 0.2$ & $1.2 \pm 0.3 .10^{5}$ & $1.6 \pm 0.1 .10^{-3}$ & $14 \pm 2$ & $n d$ & $n d$ & $n d$ \\
\hline
\end{tabular}

Table 1. Association kinetic constants $\left(\mathrm{k}_{\mathrm{on}}\right)$, Dissociation kinetic constants ( $\mathrm{k}_{\mathrm{off}}$ ), and thermodynamic dissociation constants $\left(K_{D}\right)$ for the interaction of ligands with G3 structure $\mathbf{1}, \mathrm{G} 4$ structure $\mathbf{2}$ and hairpin structure 8. nd: not determinable as no signals were observed in the range of concentrations. 